\title{
KONTRIBUSI UNGKAPAN TRADISIONAL DALAM MEMBANGUN KERUKUNAN BERAGAMA
}

\author{
Joko Tri Haryanto \\ Balai Litbang Agama Kemenag \\ e-mail: jejakagama@yahoo.co.id
}

\begin{abstract}
The Ganjuran society who live in Sumbermulyo Village, District Bambanglipuro Bantul of DIY, have ability to maintain religious harmony although those people are different religions. It is because Ganjuran society have elements that can be a social glue in their local wisdom. This research is conducted by qualitative approach to reveal local wisdom in the maintaining harmony through the form of traditional expressions and tradition of kenduri (ritual of meal). Ganjuran society has strong social harmony perspective which is expressed by traditional idiom like rukun agawe santosa crah agawe bubrah (harmony makes peaceful, hostile makes splits).

$* * *$

Masyarakat Ganjuran Desa Sumbermulyo Kecamatan Bambanglipuro Bantul DIY mampu memelihara kerukunan umat beragama, meskipun berbeda agama. Hal ini disebabkan adanya elemen-elemen yang menjadi perekat sosial berupa kearifan-kearifan lokal yang hidup dalam masyarakat Ganjuran. Penelitian yang dilakukan dengan pendekatan kualitatif ini mengungkapkan kearifan lokal pada masyarakat Ganjuran dalam memelihara kerukunan dalam bentuk ungkapanungkapan tradisional dan tradisi kenduri. Masyarakat Ganjuran memiliki pandangan sosial guyub rukun yang diungkapkan melalui berbagai ungkapan tradisional seperti rukun agawe santosa crah agawe bubrah.
\end{abstract}

Keywords: kearifan lokal, kerukunan, ungkapan tradisional, Ganjuran 


\section{A. Pendahuluan}

Masyarakat memiliki budaya-budaya dan tradisi-tradisi lokal yang secara fungsional mampu menjaga situasi lingkungannya agar tetap harmonis, baik dengan sesama manusia maupun lingkungan. Tradisi-tradisi lokal tersebut memiliki makna dan nilai penting diantaranya sebagai acuan tingkah laku bagi masyarakatnya dalam menjalani kehidupan, termasuk menghadapi perbedaan-perbedaan dalam berinteraksi dengan orang lain yang berbeda budaya. Tradisi-tradisi lokal tersebut sesungguhnya merupakan pengungkapan pengetahuan lokal (local knowledge) atau kearifan lokal (local wisdom) dari suatu masyarakat dalam menanggapi situasi lingkungannya.

Secara substansial, kearifan lokal adalah nilai-nilai yang berlaku dalam suatu masyarakat. Nilai-nilai tersebut diyakini kebenarannya dan menjadi acuan dalam bertingkah laku sehari-hari masyarakat setempat. Nilai-nilai kearifan lokal ini dipandang sebagai entitas yang sangat menentukan harkat dan martabat manusia dalam komunitasnya karena di dalamnya berisi unsur kecerdasan kreativitas dan pengetahuan lokal dari para elit dan masyarakatnya. Nilai-nilai kearifan lokal dalam bentuk tradisi maupun norma-norma sosial di masyarakat secara fungsional dapat memperkuat sistem budaya sebagai acuan dalam kehidupan masyarakat, yang kemudian dipercayai dan diakui sebagai elemen penting sehingga mampu mempertebal kohesi sosial di antara warga masyarakat. ${ }^{1}$ Dengan demikian kearifan lokal dapat menjadi elemen perekat (kohesi) sosial dalam kehidupan lintas agama, lintas kepercayaan, dan bahkan lintas budaya, sehingga dapat memberi warna kebersamaan secara dinamis dan damai, terutama dalam masyarakat yang multikultur.

Demikian pula dalam masyarakat yang berlatar belakang budaya Jawa, terdapat sistem pengetahuan yang mendasari cara bagaimana mereka berhubungan dengan orang atau pihak lain. Masyarakat atau orang Jawa telah dikenal sebagai orang yang sangat menjunjung tinggi nilai-nilai kerukunan dan keharmonisan dalam masyarakat. Dalam penelitian tentang keluarga

${ }^{1}$ John Haba, Revitalisasi Kearifan Lokal: Studi Resolusi Konflik di Kalimantan Barat, Maluku, dan Poso, (Jakarta: ICIP dan Eropean Commision, 2007), h. 11. 
Jawa, Hildred Geertz ${ }^{2}$ mengungkapkan dua kaidah penting yang mengatur sikap perilaku masyarakat Jawa hubungan sosial. Kaidah atau nilai kejawaan yang penting tentang kehidupan orang Jawa yang merupakan petunjuk moral yang mendasari tindak-tanduk atau perilaku dalam lingkungannya adalah pandangan tentang tata krama penghormatan, dan penampilan sosial yang harmonis.

Dua kaidah tersebut disimpulkan oleh Franz Magnis Suseno3, dalam kajiannya tentang Etika Jawa, sebagai prinsip hormat dan prinsip rukun. Prinsip rukun menuntut agar manusia dalam berbicara dan membawa diri harus selalu menunjukkan sikap hormat kepada orang lain sesuai derajat dan kedudukannya. Sedangkan prinsip kedua menuntut agar dalam setiap situasi manusia hendaknya bersikap sedemikian rupa sehingga tidak sampai menimbulkan konflik. Dengan demikian, setiap orang dalam masyarakat Jawa diharapkan berperilaku sesuai dengan dua prinsip tersebut. Hal ini menjadikan dalam masyarakat yang berlatar belakang Jawa mampu memelihara kerukunan.

Kearifan lokal sebagai bentuk kecerdasan lokal masyarakat mengatasi persoalan hidupnya, terutama yang berkaitan dengan hubungan atau interaksi sosial, yang dalam realitasnya meniscayakan terjadinya hubungan assosiatif maupun dissosiatif. Terlebih dalam masyarakat yang heterogen dan plural, terutama perbedaan agama, memiliki potensi terjadi konflik antarumat beragama. Tantangan semacam ini, tentunya mendorong masyarakat itu sendiri untuk memelihara nilai-nilai tradisi lokal yang mampu menyelesaikan atau meredam munculnya konflik tersebut. Di antara wilayah yang selama ini telah dikenal sebagai masyarakat yang plural tetapi mampu mempertahankan kerukunan adalah masyarakat Ganjuran, yakni di desa Sumbermulyo Kecamatan Bambanglipuro Kabupaten Bantul Yogyakarta. Di mana meskipun mayoritas masyarakatnya memeluk agama Islam, tetapi di desa ini terdapat umat Katolik dan bahkan juga gereja katolik, Gereja Hati Kudus Tuhan Yesus yang dikenal dengan Gereja Ganjuran. Umat Islam dan

\footnotetext{
${ }^{2}$ Hildred Geertz, Keluarga Jawa, (Jakarta: Grafiti Press, 1985), h. 151.

${ }^{3}$ Franz Magnis Suseno, Etika Jawa, Sebuah Analisa Falsafi tentang Kebijaksanaan Hidup Jawa, (Jakarta: PT. Gramedia Pustaka Utama, 2003), h. 38.
} 
umat Katolik di wilayah Ganjuran ini berinteraksi dengan baik dan tercipta kerukunan beragama. Tulisan ini bertujuan mendeskripsikan dinamika kerukunan dalam masyarakat Ganjuran Desa Sumbermulyo, Kecamatan Bambanglipuro Bantul Yogyakarta, dan mengungkapkan ungkapan-ungkapan tradisional yang mendukung terpeliharanya kerukunan tersebut.

\section{B. Kearifan Lokal}

E. Tiezzi, N. Marchettini, \& M. Rossini menjelaskan kearifan lokal sebagai pengetahuan yang eksplisit yang muncul dari periode panjang yang berevolusi bersama-sama masyarakat dan lingkungannya dalam sistem lokal yang sudah dialami bersama-sama. Secara substansial, kearifan lokal itu adalah nilai-nilai yang berlaku dalam suatu masyarakat. Nilai-nilai yang diyakini kebenarannya dan menjadi acuan dalam bertingkah-laku sehari-hari masyarakat setempat. Kearifan yang tersebut diungkapkan dalam bentuk kata-kata bijak (falsafah) berupa nasehat, pepatah, pantun, syair, folklor (cerita lesan) dan sebagainya; aturan, prinsip, norma dan tata aturan sosial dan moral yang menjadi sistem sosial; ritus, seremonial atau upacara tradisi dan ritual; serta kebiasaan yang terlihat dalam perilaku sehari-hari dalam pergaulan sosial. ${ }^{4}$

Salah satu bentuk kearifan lokal tersebut adalah ungkapan-ungkapan tradisional. Ungkapan tradisional adalah kata atau kelompok kata yang memiliki makna kiasan, konotatif, simbolis yang berasal dari tradisi atau kebiasaan turun-temurun masyarakat lokal dan diyakini mempunyai fungsi. Ungkapan-ungkapan tersebut disarikan dari pengalaman panjang masyarakat yang dimunculkan dari kecerdasan lokal menjadi kebijaksanaan bersama masyarakat. Sebagai sebuah tradisi dan folklor lisan, maka ungkapan tradisional mempunyai nilai-nilai yang dijabarkan dari pandangan hidup masyarakat pembuatnya. Dengan mengambil nilai-nilai ungkapan tradisional, maka masyarakat bisa memahami bagaimana nenek moyang atau masyarakat yang menghasilkan ungkapan tersebut memandang dan menyikapi hidup. Agar tercipta keselarasan dan keharmonisan, oleh karena itu secara

4 Rohimin, et.al, Harmonisasi Agama dan Budaya di Indonesia, (Jakarta: Balai Litbang Agama Jakarta, 2009), h. 207. 
umum masyarakat Jawa dipandang sebagai masyarakat yang selalu berpijak pada terciptanya harmoni manusia dengan Tuhan, sesamanya, masyarakat, dan lingkungan. ${ }^{5}$

Terkait dengan persoalan interaksi antarmanusia, terutama kerukunan hidup dalam masyarakat, menurut John $\mathrm{Haba}^{6}$, setidaknya ada enam signifikansi serta fungsi sebuah kearifan lokal jika hendak dimanfaatkan sebagai salah satu bentuk pendekatan dalam menyelesaikan sebuah konflik. Pertama, sebagai penanda identitas sebuah komunitas. Kedua, elemen perekat (aspek kohesif) lintas warga, lintas agama dan kepercayaan. Ketiga, kearifan lokal tidak bersifat memaksa atau dari atas (top down), tetapi sebuah unsur kultural yang ada dan hidup dalam masyarakat. Karena itu, daya ikatnya lebih mengena dan bertahan. Keempat, kearifan lokal memberikan warna kebersamaan bagi sebuah komunitas. Kelima, local wisdom akan merubah pola pikir dan hubungan timbal balik individu dan kelompok, dengan meletakkannya di atas common ground/kebudayaan yang dimiliki. Keenam, kearifan lokal dapat berfungsi mendorong terbangunnya kebersamaan, apresiasi sekaligus sebagai sebuah mekanisme bersama untuk menepis berbagai kemungkinan yang meredusir, bahkan merusak, solidaritas komunal, yang dipercayai berasal dan bertumbuh di atas kesadaran bersama, dari sebuah komunitas terintegrasi.

\section{Ungkapan Tradisional Masyarakat Jawa}

Budaya Jawa yang menekankan hidup rukun menjadikan masyarakat berupaya menjaga kerukunan tersebut. Nilai-nilai budaya Jawa, seperti sikap penghormatan, sikap rukun, toleransi, dan sebagainya menjadi acuan moral dan tingkah laku dalam berhubungan antarumat beragama. Pengalaman panjang orang Jawa dalam menjalani kehidupan bersama, berinteraksi dengan sesama manusia, pencapaian tujuan pribadinya maupun tujuan bersama menjadikan orang Jawa arif dalam menjalaninya. Nilai budaya ini

${ }^{5}$ Sri Harti Widyastuti, "Reaktualisasi Ungkapan Tradisional Jawa sebagai Sumber Kearifan Lokal dalam Masyarakat untuk Penguat Kepribadian Bangsa”, makalah, Konggres Bahasa Jawa ke-5 dikutip dalam http://ki-demang.com/kbj5, diunduh 14 September 2012.

6 Dalam Alpha Amirrachman, Revitalisasi Kearifan Lokal: Studi Resolusi Konflik di Kalimantan Barat, Maluku dan Poso, (Jakarta: ICIP dan European Commission (EC), 2007), h. 334-335. Dapat diakses pada www.lsaf.org/content/view/176/150/, diunduh 17 Juni 2010. 
diungkapkan dalam berbagai tradisi yang didalamnya mengandung kearifan lokal dalam menjalani hidup bersama. Tradisi-tradisi tersebut menjadi kristalisasi kecerdasan masyarakat Jawa menghadapi persoalan hidup yang muncul dalam hubungannya dengan sesama manusia.

Di antara tradisi masyarakat yang menyimpan kearifan lokal tersebut adalah tradisi lesan yang berupa ungkapan-ungkapan tradisional. Menurut Dananjaya ${ }^{7}$, ungkapan tradisional ini awalnya dinyatakan secara spontan, kemudian menjadi kebiasaan dan dapat dikatakan klise. Makna dalam ungkapan ini dapat bersifat instruktif, inperatif, ataupun preventif. Biasanya ungkapan-ungkapan tradisional bersifat anonim atau tidak diketahui siapa penciptanya. Ciri-ciri lainnya dari ungkapan tradisional ini adalah:

1. Merupakan alat pencerminan suatu angan-angan yang bersifat kolektif;

2. Sebagai alat pengesahan pranata;

3. Sebagai media pendidikan non-formal;

4. Sebagai alat pemaksa dan pengawas, agar norma-norma masyarakat dapat dipenuhi.

Ungkapan tradisional adalah kata atau kelompok kata yang memiliki makna kiasan, konotatif, simbolis yang berasal dari tradisi atau kebiasaan turun-temurun masyarakat lokal dan diyakini mempunyai fungsi. Ungkapanungkapan tersebut disarikan dari pengalaman panjang masyarakat yang dimunculkan dari kecerdasan lokal menjadi kebijaksanaan bersama masyarakat. Sebagai sebuah tradisi dan folklor lisan, maka ungkapan tradisional mempunyai nilai-nilai yang dijabarkan dari pandangan hidup masyarakat pembuatnya. Dengan mengambil nilai-nilai ungkapan tradisional, maka masyarakat bisa memahami bagaimana nenek moyang atau masyarakat yang menghasilkan ungkapan tersebut memandang dan menyikapi hidup. Agar tercipta keselarasan dan keharmonisan, oleh karena itu secara umum masyarakat Jawa dipandang sebagai masyarakat yang selalu berpijak pada terciptanya harmoni manusia dengan Tuhan, sesamanya, masyarakat, dan lingkungan. ${ }^{8}$

${ }^{7}$ Samidi Khalim, Tradisi Lisan MasyarakatJawa, (Semarang: Prima Media Press, 2009), h. 33.

${ }^{8}$ Sri Harti Widyastuti, "Reaktualisasi Ungkapan Tradisional Jawa Sebagai Sumber Kearifan Lokal dalam Masyarakat untuk Penguat Kepribadian Bangsa”, makalah, Konggres Bahasa Jawa ke-5 dikutip dalam http://ki-demang.com/kbj5, diunduh 14 September 2012. 
Dengan demikian, ungkapan-ungkapan tradisional dalam masyarakat memiliki peran sebagai acuan moral dalam menjalani kehidupan bersama secara rukun dan damai, sekaligus menjadi media transformasi nilai-nilai kerukunan tersebut pada masyarakat dan generasi selanjutnya. Masyarakat menjalani interaksi sosialnya dengan orang lain akan dinilai dari kesesuaiannya dengan nilai-nilai moralitas tersebut. Oleh karena itu, ungkapanungkapan tradisional dalam masyarakat Jawa tidak hanya berupa ungkapan yang bernada positif, tetapi juga menggunakan istilah negatif sebagai bentuk kritik terhadap perilaku yang negatif tersebut. Ungkapan-ungkapan tersebut, baik yang positif maupun negatif sama-sama memiliki fungsi sebagai acuan moral, tentang apa yang baik dan buruk dalam perilaku manusia dalam kehidupannya.

Ungkapan Jawa terinci dalam banyak jenis, diantaranya berupa: wangsalan, parikan, sanepa, tembung entar, paribasan, bebasan, dan saloka. Wangsalan itu adalah ungkapan yang ungkapan sejenis tebakan atau tekateki yang jawaban atau tebakannya berupa suku kata tersamar di dalam tubuh ungkapan itu sendiri. Parikan adalah ungkapan yang memiliki aturan persajakan, sampiran, isi, dan jumlah baris yang dibutuhkan. Sanepa adalah ungkapan yang berfungsi untuk menggambarkan situasi atau keadaan secara berlebih atau menyangatkan dengan cara pengandaian. Tembung entar adalah ungkapan yang maknanya kiasan, berbentuk perumpamaan, dan berfungsi untuk menyindir tingkah laku atau sifat seseorang.

Paribasan adalah ungkapan yang digunakan secara ajeg/tidak boleh diganti, serta tidak berupa perumpamaan, fungsinya untuk menggambarkan keadaan, tingkah laku atau kehendak seseorang. Bebasan merupakan ungkapan yang berisi perumpamaan, diungkapkan secara ajeg, dan berfungsi untuk mengungkapkan keadan dan tingkah laku orang yang digambarkan. Fokus perumpamaan terletak pada tingkah laku dan keadaannya. Saloka adalah ungkapan yang menggambarkan perilaku dan keadaan seseorang dengan perumpamaan. Adapun yang dianalogikan/ diperumpamakan adalah orangnya. ${ }^{9}$

\footnotetext{
${ }^{9}$ Endang Nurhayati, "Nilai-Nilai Luhur dalam Ungkapan Jawa sebagai Fondamen Kehidupan Masyarakat Berbudaya", makalah, Konggres Bahasa Jawa ke-5 dikutip dalam http://kidemang.com/kbj5, diunduh 14 September 2012.
} 
Selain jenis pengungkapan tersebut, masih terdapat jenis lainnya seperti pepali ora ilok dan kereta basa atau jarwa dhosok. Pepali ora ilok merupakan bentuk larangan melakukan sesuatu yang dipandang tidak baik atau berakibat tidak baik bagi pelakunya. Sedangkan kereta basa atau jarwa dhosok adalah mengandaikan makna dari nama sesuatu atau kata tertentu dengan menganggapnya sebagai akronim dengan kepanjangannya sebagai makna yang dimaksud.

\section{Sekilas tentang Masyarakat Ganjuran}

Nama Ganjuran sudah banyak dikenal orang, merujuk pada wilayah di Desa Sumbermulyo Kecamatan Bambanglipuro Bantul Yogyakarta. Nama Ganjuran sendiri merupakan nama budaya, dan bukan nama resmi, karena dalam administrasi kependudukan dan pemerintahan di Kabupaten Bantul tidak ada kecamatan, desa, atau pedukuhan yang bernama Ganjuran. Namun Yogyakarta, khususnya di Bantul mengenal wilayah Ganjuran ini, sebagai suatu wilayah meliputi atau yang berada di Desa Sumbermulyo Kecamatan Bambanglipuro. Nama Ganjuran ini lebih dikenal dibandingkan nama Desa Sumbermulyo sendiri. Hal ini karena pada zaman penjajahan Belanda, di desa ini terdapat Pabrik Gula Ganjuran yang cukup besar. Lebih-lebih di desa ini ada Gereja Hati Kudus Tuhan Yesus yang lebih dikenal dengan nama Gereja Ganjuran dan menjadi tujuan wisata spiritual oleh umat Katolik.

Masyarakat di Desa Sumbemulyo bahkan warga di luar wilayah desa ini pun dalam pembicaraan informal mengenalkan diri sebagai orang Ganjuran. Oleh karena itu, apabila orang menyebut Ganjuran, bisa dalam pengertian wilayah kecamatan Bambanglipuro, lebih khusus lagi adalah Desa Sumbermulyo, atau lebih khusus lagi adalah tiga dukuh yang menjadi inti wilayah Ganjuran sendiri, yaitu Dukuh Kaligondang, Dukuh Gedogan, dan Dukuh Jogodayoh.

Nama Ganjuran sendiri sekarang secara formal menjadi nama jalan utama Desa Sumbermulyo. Di jalur jalan Ganjuran ini, bahkan lebih ramai dan memiliki banyak fasilitas umum dibandingkan di wilayah Kecamatan Bambanglipuro lainnya termasuk kota kecamatan itu sendiri. Di sepanjang jalan ini terdapat Gereja Katolik Hati Kudus Tuhan Yesus yang merupakan Gereja Paroki yang membawahi beberapa Kecamatan di wilayah Kabupaten Bantul, 
Kantor Urusan Agama (KUA) Kecamatan Bambanglipuro, Kantor Kepolisian Sektor Bambanglipuro, Bank BRI, Rumah Sakit Santa Maria, Kantor Desa Sumbermulyo, Pasar Gatak, dan beberapa lembaga pendidikan.

Desa Sumbermulyo terbagi dalam 16 pedukuhan dan 108 RT. Penduduk Desa Sumbermulyo tercatat sebanyak 18.002 jiwa. Sebagian besar masyarakatnya berprofesi sebagai petani yakni 4.633 orang berprofesi petani dan buruh tani, atau $25,7 \%$ dari penduduk, dan Lahan persawahan juga mencapai $60 \%$ dari seluruh luas Desa Sumbermulyo. ${ }^{10}$ Kondisi ini menciptakan budaya masyarakat pedesaan agraris/pertanian. Sebagaimana juga lingkungan Yogyakarta yang termasuk pusat kebudayaan Jawa, maka masyarakat Sumbermulyo juga memegang tradisi dan nilai-nilai budaya Jawa.

Namun menariknya, masyarakat di Desa Sumbermulyo ini mayoritas berafialiasi pada organisasi keagamaan Muhammadiyah yang dikenal sebagai ormas yang memiliki orientasi purifikasi (pemurnian) ajaran Islam, sehingga seringkali diasumsikan anti-tradisi populer keagamaan. Meskipun demikian, Paguyuban Macapatan, Shalawat Montro, dan wayang juga ada anggotanya dan pengurusnya tokoh lokal Muhammadiyah. Selain Muhammadiyah, juga ada ormas Islam Nahdlatul Ulama (NU), dan setelah peristiwa gempa bumi yang melanda Yogyakarta, dimana Desa Sumbermulyo termasuk wilayah yang dianggap paling parah, bermunculan kelompok-kelompok Islam lainnya seperti Lembaga Dakwah Islam Indonesia (LDII), Hizbut Tahrir Indonesia (HTI), Majelis Tafsir Al-Qur'an (MTA), Majelis Dhuha, dan sebagainya.

Di Desa Sumbermulyo terdapat beberapa agama yang dipeluk oleh masyarakatnya, yaitu Islam, Katolik, dan Kristen. Umat Islam merupakan umat mayoritas di Desa Sumbermulyo (79,3\%). Hubungan masyarakat antarumat beragama di Desa Sumbermulyo ini terjalin dengan baik dan rukun. Hal ini setidaknya dapat dilihat dari tata ruang desa, di mana antara umat Islam dan umat Katolik saling membaur. Beberapa fasilitas keagamaan maupun pendidikan milik umat Islam dan umat Katolik saling berdekatan lokasinya. Dalam radius areal satu kilometer, fasilitas-fasilitas keagamaan dan pendidikan Islam dan Katolik berdiri berdampingan. Misalnya di dekat kompleks Gereja Ganjuran, Rumah Sakit Santa Elizabeth, Panti Asuhan Santa

${ }^{10}$ Data Potensi Desa Sumbermulyo tahun 2012 
Maria, Asrama Putri Santa Elizabeth, dan SMA Stella Duce terdapat Masjid alQomar, TK Aisiyah, dan TK Bina Insani. SMP Kanisius berdampingan dengan masjid Al-Anma, SD Muhammadiyah berdampingan dengan SD Kanisius. Kesemuanya itu berada dalam wilayah yang dikenal sebagai wilayah Ganjuran tersebut.

Tabel 1.

Komposisi penduduk berdasarkan agama tahun 2011

\begin{tabular}{|c|c|c|c|c|c|}
\hline No. & Agama & Laki-laki & Perempuan & Jumlah & Prosentase \\
\hline 1. & Islam & 6.974 & 7.347 & 14.321 & $79,3 \%$ \\
\hline 2. & Katolik & 1.747 & 1.936 & 3.683 & $20,3 \%$ \\
\hline \multirow[t]{2}{*}{3.} & Kristen & 27 & 33 & 60 & $0,4 \%$ \\
\hline & Total & 8.748 & 9.316 & 18.064 & $100 \%$ \\
\hline
\end{tabular}

Sumber: Laporan Pembangunan Desa Sumbermulyo tahun 2011

Sementara itu, penduduk yang Muslim dan Katolik saling berbaur dalam lingkungan RT dan pedukuhan masing-masing, terutama di wilayah Ganjuran. Meskipun demikian di Desa Sumbermulyo ini terdapat dua dukuh yang mayoritas Katolik, yaitu Dukuh Kanutan dan Dukuh Caben. Pusat keagamaan umat Katolik adalah Gereja Hati Kudus Tuhan Yesus atau Gereja Ganjuran. Gereja Ganjuran ini malah bisa dikatakan sebagai gereja paling awal di Indonesia yang mempraktekkan inkulturasi, di mana liturgi yang umumya menggunakan bahasa Latin, di Gereja Ganjuran sudah mengunakan bahasa Jawa. Saat sekarang ini, bangunan Gereja Ganjuran telah dibangun kembali pascagempa dalam bentuk bangunan Joglo. Tidak hanya itu, patungpatung, panel dan relief di lingkungan gereja ini juga bercorak Jawa.

Dari segi pendidikan, Desa Sumbermulyo ini bisa dikatakan lebih awal mengenal pendidikan sekolah formal dibandingkan daerah lain. Hal ini karena pada saat keluaga Schmutzer mengelola Pabrik Gula Ganjuran, keluarga ini juga membangun sekolah-sekolah dan rumah sakit untuk pribumi. Tahun 1919 di wilayah Ganjuran in telah didirikan Standard School (Sekolah Dasar), dan antara tahun 1923-1930 telah berdiri sebanyak 12 sekolah baik di wilayah Ganjuran maupun sekitarnya. Sekolah-sekolah ini sekarang berada di bawah naungan Lembaga Kanisius. Pada saat sekarang ini 
di Desa Sumbermulyo tidak hanya lembaga-lembaga pendidikan Kanisius saja tetapi juga dari sekolah negeri dan lembaga pendidikan Muhammadiyah. Antara pendidikan yang dikelola umat Islam dan Katolik berimbang, sehingga memberi kesempatan yang sama pada kedua umat beragama dalam pengembangan diri keluarga terutama anak-anak mereka.

\section{E. Dinamika Kerukunan Masyarakat Ganjuran}

Ganjuran dapat dilihat dalam kerangka sosiologi pedesaan sebagai gambaran prototype masyarakat pedesaan Jawa. Masyarakat pedesaan yang ramah terhadap semua orang, di mana apabila mereka saling bertemu mereka saling menyapa, bahkan terhadap orang yang tidak dikenal pun apabila berpapasan di jalan akan saling menegur, meski hanya dengan mengucapkan "mangga". Hal ini karena bagi masyarakat, hidup itu harus srawung, istilah untuk menunjukkan sikap mau mengenal dan bersama dengan orang lain.

Masyarakat Ganjuran merupakan masyarakat yang plural. Di desa Sumbermulyo, khususnya di lingkungan Ganjuran terdapat umat Islam, umat Katolik, dan umat Kristen yang hidup secara membaur dan dampingan secara damai dan rukun. Interaksi sosial yang terjalin di dalamnya berjalan dengan baik, terutama karena didukung dengan budaya Jawa yang melingkupi masyarakat Ganjuran. Kerukunan di Desa Sumbermulyo ini terjalin dalam dinamika atau proses sosial, yang meliputi interaksi assosiatif maupun dissosiatif, sehingga situasi perdamaian yang ditunjukkan oleh masyarakat Ganjuran, termasuk hubungan antarumat beragama, umat Islam dan umat Katolik dalam berbagai aktivitas kemasyarakat.

Dinamika dalam sifat assosiatif dapat dilihat dalam aktivitas bersama warga masyarakat Ganjuran yang guyub rukun. Guyub artinya kebersamaan, di mana berbagai kegiatan kemasyarakatan dilaksanakan secara bersamasama. Hal ini dilakukan oleh masyarakat Sumbermulyo tanpa memandang agama. Kegiatan yang merupakan kepentingan bersama, akan dilaksanakan bersama oleh warga dan partisipasi seluruh warga tanpa memandang berbedaan agama. 
Tabel 2.

Aktivitas Sosial Bersama Umat Beragama

\begin{tabular}{|c|c|}
\hline Jenis Aktivitas & Bentuk aktivitas \\
\hline Gotong royong, kerja bakti & $\begin{array}{l}\text { kegiatan untuk kepentingan lingkungan, seperti } \\
\text { membenahi saluran air, kebersihan lingkungan, ke- } \\
\text { bersihan makam. }\end{array}$ \\
\hline $\begin{array}{l}\text { Saling mengucapkan selamat } \\
\text { hari raya }\end{array}$ & $\begin{array}{l}\text { Ujungan, saling mengucapkan sugeng riyadi, sugeng } \\
\text { natal. }\end{array}$ \\
\hline sambatan & $\begin{array}{l}\text { Membuat tarub untuk perhelatan, membetulkan } \\
\text { rumah, membersihkan kebun. }\end{array}$ \\
\hline Acara-acara kenduri warga & $\begin{array}{l}\text { Doa bersama untuk keselamatan, mengundang dan } \\
\text { membagikan makanan pada semua warga. }\end{array}$ \\
\hline $\begin{array}{l}\text { Perawatan jenasah/orang } \\
\text { meninggal }\end{array}$ & $\begin{array}{l}\text { Mengumumkan berita lelayu/kematian, baik yang islam, } \\
\text { katolik, maupun kristen, asalkan warga melalui pengeras } \\
\text { suara masjid. } \\
\text { Pengurusan jenasah, terutama mengantar, menggotong } \\
\text { ke makam semuanya ikut. }\end{array}$ \\
\hline Nyadran & $\begin{array}{l}\text { Nyekar di makam, mengirimkan doa untuk leluhur di } \\
\text { makam Lokasi pemakaman bersama. }\end{array}$ \\
\hline
\end{tabular}

Sumber: Data hasil penelitian

Aktivitas-aktivitas dalam lingkungan Ganjuran ini merupakan aktivitas dari warga tanpa memandang kelompok agama, dan bertujuan untuk kepentingan bersama atau semua warga itu sendiri. Kegiatan bersama yang dilakukan semua warga untuk kepentingan warga berupa kegiatan gotong royong dan kerja bakti. Ada pula kegiatan yang dilakukan bersama tanpa memandang kelompok agama dalam lingkungan tertentu yang tujuannya untuk kepentingan pribadi seseorang atau keluarga yang meminta tolong bantuan. Hal ini biasa disebut sambatan, atau nyambat.

Selain rasa guyub yang ditunjukkan dengan kegiatan bersama, rasa guyub juga ditunjukkan melalui sikap saling menghormati dan saling memberikan selamat terhadap tetangga pada saat lebaran maupun natal. Umumnya ucapan mereka adalah "ngaturaken sugeng riyadi", dan memohon 
maaf atas kesalahan mereka. Demikian juga, pada saat natal, umat Islam yang bersua tetangganya yang Katolik dan Kristen akan mengucapkan selamat natal dengan ucapan "sugeng Natal". Kegiatan yang mengandung unsur agama, juga ada yang melibatkan semua warga tanpa memandang perbedaan agama. Di Desa Sumbermulyo, acara tradisi kenduri dan tradisi nyadran dilakukan bersama-sama baik umat Islam maupun Katolik. Kegiatan bernuansa keagamaan lainnya adalah perawatan jenazah. Apabila ada warga yang meninggal dunia, baik Muslim maupun Katolik atau Kristen, akan diumumkan melalui pengeras suara di masjid. Selain itu, pengurusan jenazah, terutama mengantar dan menggotong ke makam semua warga dan tetangga ikut serta.

Aktivitas umat Katolik terutama yang dilaksanakan melalui aktivitas Gereja Ganjuran juga mendukung dinamika yang positif, karena membuka diri terhadap partisipasi umat non-Katolik untuk dalam kegiatan gereja, dan memberi keuntungan bagi masyarakat sekitar. Misalnya, kegiatan kenduri agung dalam rangka Prosesi Agung Gereja Ganjuran yang dilaksanakan pada akhir bulan Juni setiap tahunnya sebagai penghormatan terhadap Hati Kudus dan syukur kepada Tuhan. Sebelum dilaksanakan kegiatan proses agung, gereja mengadakan kenduri terlebih dahulu sebagaimana dalam tradisi Jawa untuk melakukan selamatan apabila akan menyelenggarakan hajatan. Gereja Ganjuran dalam menyelenggarakan kenduri proses agung ini selain mengundang perwakilan lingkungan jamaat Katolik di wilayah kerja Paroki Ganjuran, juga mengundang warga sekitar gereja ganjuran baik yang Muslim maupun kristen. Dalam acara kenduri itu, pembacaan doa dilakukan oleh lima tokoh agama, yaitu Islam, Katolik, Kristen, Hindu, dan buda, serta satu orang dari penghayat kepercayaan.

Gereja Ganjuran sebagai bagian dari desa Sumbermulyo, juga turut berpartisipasi dalam pembangunan di desa Sumbermulyo, misalnya dengan membantu bantuan pada warga miskin, dukungan dana bagi pembangunan gerbang Desa Sumbermulyo, dan penerangan jalan Ganjuran. Pada waktu terjadi bencana gempa bumi tahun 2010 lalu, Gereja Ganjuran juga turut membantu upaya pemulihan bersama dengan pemerintah dan lembagalembaga lainnya. Gereja Ganjuran juga menyerahkan pengelolaan parkir kegiatan gereja pada acara-acara khusus, seperti kegiatan malam jumat 
pertama tiap bulan dan prosesi agung dengan pengunjung mencapai 1000-an lebih, kepada Karangtaruna Desa Sumbermulyo.

Masyarakat Ganjuran yang heterogen tidak dipungkiri juga menimbulkan dinamika hubungan antar warga yang berbeda agama, terutama antara umat Islam dan Katolik. Lingkungan sosial yang memiliki keragaman, seperti perbedaan agama, memiliki keniscayaan munculnya perbedaan baik aktivitas keagamaan masing-masing, cara pandang terhadap lingkungan mereka, hubungan di antara mereka. Perbedaan demikian ini dapat menimbulkan konflik pada saat perbedaan tersebut mengarah pada kepentingan yang bertentangan.

Masyarakat Ganjuran Desa Sumbermulyo dalam perjalanan dari waktu ke waktu mengalami dinamika hubungan antara umat Islam dan umat Katolik, termasuk hubungan yang bernuansa konflik. Persoalan antara umat Islam dan Katolik yang relatif masih baru adalah masalah pengungsi Merapi tahun 2010 lalu. Pada saat bencana gunung merapi meletus pada bulan November 2010, sekelompok pengungsi sekitar 100-an orang dari Cangkringan berlindung dan ditampung di gereja Ganjuran. Sebagian pengungsi tersebut adalah Muslim. Kemudian muncul isu, gereja melakukan pengkristenan terhadap pengungsi yang Muslim tersebut. Sekelompok orang yang mengatasnamakan Forum Umat Islam (FUI) meminta agar pengungsi dipindahkan dari gereja. Orang-orang ini umumnya berasal dari luar daerah Ganjuran sendiri. Sri Sultan Hamengkubuwana X ikut turun tangan menengahi, dengan memindahkan pengungsi ke rumah dinas Bupati Bantul. Meskipun sempat memanas, peristiwa ini tidak sampai anarkhis, karena tuntutan tersebut segera dapat didialogkan dengan pemerintah desa dan tokoh-tokoh masyarakat.

Masalah berikutnya adalah masalah rencana perkawinan seorang perempuan Muslim dengan pemuda katolik di tahun 2011. Pihak keluarga perempuan sudah setuju dengan bukti surat pengantar perkawinan dari kelurahan. Namun sebelum perkawinan dilangsungkan, sekelompok orang mendatangi gereja dan meminta perkawinan tersebut dibatalkan, karena menganggap perkawinan tersebut adalah kristenisasi. Akhirnya oleh Romo Pendeta masalah itu dikembalikan kepada keluarga, dan dianggap sebagai masalah tidak melanjutkan perkawinan tersebut. 
Relasi antara umat Islam dan umat Katolik di Ganjuran, tidak dipungkiri juga mengandung potensi-potensi konflik. Potensi ini menjadi laten, yang mana dapat muncul dipermukaan menjadi konflik yang manifes. Namun potensi ini juga dapat hanya menjadi laten selama masyarakat mampu mengelolanya atau masyarakat menghendaki hal tersebut tidak dipermasalahkan untuk menjaga kerukunan sesama warga. Potensi konflik tersebut berupa politik lokal dalam pemilihan Lurah desa, Kepala Dukuh, Ketua RT, maupun pemilihan anggota Badan Perwakilan Desa (BPD). Jabatan-jabatan tersebut bertujuan melayani masyarakat lintas agama, tetapi terkadang muncul sentimen keagamaan sebagai strategi politik yang berpotensi mengganggu kerukunan beragama.

Hubungan dalam perbedaan tidak dipungkiri juga menimbulkan prejudice atau prasangka negatif terhadap kelompok lain. Di antaranya terkait dengan kekuasaan atau politik lokal, di mana ada kecurigaan bahwa kelompok yang tengah memegang jabatan menggunakan jabatannya tersebut untuk memihak kelompok agamanya. Kecurigaan lainnya adalah isu-isu kristenisasi, yakni kecurigaan bahwa ada upaya-upaya dari pihak Katolik untuk mengajak warga Muslim masuk menjadi Katolik. Di antara yang dipandang menjadi modus kristenisasi adalah melalui bantuan-bantuan ekonomi dan kesehatan. Modus lain yang dianggap masih berjalan adalah melalui perkawinan campuran dan pekerjaan.

Potensi konflik lainnya adalah kontroversi dari pelaksanaan kegiatan kenduri secara bersama, undangan peringatan natal bersama, dan nyadran. Polemik atas hal tersebut tidak saja karena dianggap sebagai kegiatan keagamaan yang menurut sebagian warga tidak seharusnya diikuti oleh umat agama lain, tetapi juga tradisi-tradisi tersebut dapat dikategorikan bid'ah yang tidak memiliki tuntunan dalam agama.

Interaksi sosial masyarakat Ganjuran yang di dalamnya terdapat pengalaman maupun potensi konflik, tetapi masyarakat mampu meredamnya sehingga tercapai hubungan yang rukun. Kondisi kerukunan yang tercipta di Ganjuran upaya perdamaian yang terwujud mendukung harapan masyarakat untuk hidup bersama. Kerukunan antara umat Islam dan umat Katolik menunjukkan adanya toleransi dan ketertiban sosial sebagai dasar hubungan antarumat beragama. Situasi positif yang diharapkan bersama dan terbentuk 
dalam masyarakat adalah situasi harmoni di mana terdapat sikap saling menghargai dan menghormati terhadap keberadaan orang lain. Masingmasing kelompok umat memiliki identitas sosial dan budaya yang mendukung eksistensinya, sehingga dengan kondisi yang penuh toleransi dan harmoni, maka masyarakat dapat saling bekerjasama dan kemandirian dalam beraktivitas. Kerukunan di Ganjuran juga menumbuhkan kebebasan menjalankan aktivitas kelompok, tradisi, dan kepercayaannya, tetapi sekaligus tetap merasa sebagai bagian yang satu dalam masyarakat Ganjuran. Kebersamaan dalam berbagai tradisi dan aktivitas sosial menunjukkan kerukunan yang berdasarkan nilai-nilai kesetaraan tersebut.

Kerukunan antar umat beragama di wilayah Ganjuran telah terbentuk sejak dahulu. Hal ini ditunjukkan dengan berkembangnya agama Katolik di wilayah ini yang tidak menimbulkan gejolak dan konflik dengan masyarakat sekitar. Terdapat beberapa hal yang menjadi faktor pendukung terciptanya kondisi kerukunan pada masyarakat Ganjuran ini, di antaranya dari sejarah gereja ganjuran, inkulturasi gereja dengan budaya Jawa, hubungan kekeluargaan, ajaran agama yang mendorong kerukunan, dan budaya Jawa yang berorientasi pada kerukunan dan harmoni sosial.

\section{F. Ungkapan Tradisional dalam Memelihara Kerukunan}

Satu faktor yang mendukung terwujudnya kerukunan umat beragama di Ganjuran Desa Sumbermulyo adalah budaya Jawa. Masyarakat Ganjuran sebagai etnis Jawa menganut sistem nilai Jawa yang sangat menjunjung tinggi prinsip hormat dan rukun. Budaya Jawa dalam perikehidupan masyarakat menjadi acuan moral dan tingkah laku banyak terdapat dalam ungkapanungkapan yang sering muncul dalam pembicaraan ada saat terjadi suatu peristiwa tertentu, tidak terkecuali dalam konteks hubungan antar manusia dan antar umat beragama. Ungkapan tradisioanl tersebut mengandung kearifan lokal yang mampu mendorong masyarakatnya pada kerukunan hidup. Persoalan dalam interaksi sosial, bagaimana menjaga keharmonisan dan mencegah konflik, dikerangkai dengan norma kerukunan yang secara eksplisit disampaikan melalui ungkapan tradisional.

Salah satu ungkapan yang langsung berkaitan dengan tema kerukunan adalah paribasan rukun agawe santosa crah agawe bubrah. Secara semantik, 
kata rukun menunjukkan kondisi damai dan bermakna pula sikap guyub, sehingga muncul pula istilah guyub rukun. Kata guyub rukun merupakan tautologi, atau pengulangan yang memiliki arti yang sama atau hampir sama sehingga bermakna melebihkan atau menekankan arti tersebut. Kata guyub sendiri berarti rukun, kebersamaan, bersama-sama, sedangkan rukun adalah kondisi damai tanpa konflik. Dengan demikian guyub rukun adalah kondisi rukun tanpa konflik dalam kehidupan bersama dan berusaha dalam kebersamaan. Sementara santosa berarti kuat atau kokoh. Dalam konteks sosial, rukun agawe santosa berarti bahwa kondisi yang rukun dan damai akan memberi kesempatan pada masyarakat untuk menguatkan diri, misalnya kuat secara ekonomi yang berarti meningkatnya kesejahteraan.

Sebaliknya crah agawe bubrah artinya konflik akan membuahkan kerusakan. Crah artinya perpecahan, pertikaian, dan konflik; sedangkan bubrah artinya bubar, rusak, bercerai berai. Kondisi yang diwarnaai perpecahan atau konflik tidak saja menjadikan situasi tidak rukun, tetapi juga menyebabkan kerusakan. Dengan demikian, melalui paribasan ini, masyarakat mengkerangkai hidup bersama orang lain dalam suatu lingkungan masyarakat harus bersikap rukun dan berusaha menjaga kerukunan sehingga dapat menguatkan masyarakat, dan sebaliknya menjaga sikap dan lingkungannya agar tidak $c r a h$ atau berkonflik dengan orang lain karena akan mengakibatan sesuatu yang buruk bagi diri maupun masyarakat.

Norma rukun ini dalam prakteknya menuntut anggota masyarakat untuk menjaga hubungan baik dengan orang lain. Setiap orang dituntut untuk bersikap yang baik, dan pantas dalam hubungannya dengan orang lain sehingga tercipta kerukunan hidup bersama. Sikap yang buruk terhadap orang lain akan memancing munculnya crah atau konflik. Kondisi ideal ini menekankan sikap dan perilaku yang menjaga kerukunan tersebut, sehingga muncul ungkapan lainnya yang mendorong terwujudnya kerukunan, dan dalam kajian konflik relevan dengan istilah resolusi konflik. Berikut ungkapan-ungkapan tradisional tesebut: 
Tabel 3.

Ungkapan Tradisional sebagai Resolusi Konflik

\begin{tabular}{|c|c|c|}
\hline $\begin{array}{l}\text { Fungsi Resolusi } \\
\text { Konflik }\end{array}$ & Ungkapan Tradisional Jawa & Makna \\
\hline \multirow[t]{9}{*}{$\begin{array}{l}\text { Kondisi ideal } \\
\text { (rukun) }\end{array}$} & Guyub rukun & $\begin{array}{l}\text { Kebersamaan dalam damai tanpa kon- } \\
\text { flik. }\end{array}$ \\
\hline & $\begin{array}{l}\text { Rukun agawe santosa, crah } \\
\text { agawe bubrah }\end{array}$ & $\begin{array}{l}\text { Rukun membuat kuat, konflik membuat } \\
\text { rusak. }\end{array}$ \\
\hline & Memayu hayuning bawana & Mengindah-indahkan alam semesta. \\
\hline & Mangan ora mangan kumpul & $\begin{array}{l}\text { Makan tidak makan berkumpul; mes- } \\
\text { kipun bagaimana keadaan (ekonomi) } \\
\text { tetap bersama. }\end{array}$ \\
\hline & $\begin{array}{l}\text { Dudu sanak dudu kadang yen } \\
\text { matimelu kelangan }\end{array}$ & $\begin{array}{l}\text { Bukan saudara tetapi kalau meninggal } \\
\text { ikut merasa kehilangan; meskipun orang } \\
\text { lain karena merasa dekat kalau ada } \\
\text { musibah yang menimpanya yang lain } \\
\text { ikut merasakan juga. }\end{array}$ \\
\hline & Sabya mati sabya mukti & $\begin{array}{l}\text { Bersama sama mati bersama-sama ter- } \\
\text { hormat; hidup rukun dalam keadaan } \\
\text { musibah maupun nikmat; Hidup rukun } \\
\text { sampai mati menjemput. }\end{array}$ \\
\hline & Tuna sathak bathi sanak & $\begin{array}{l}\text { Rugi sedikit untung saudara; rugi sedikit } \\
\text { tidak apa-apa karena telah mendapat } \\
\text { keuntungan berupa persaudaraan. }\end{array}$ \\
\hline & $\begin{array}{l}\text { Witing tresna jalaran saka } \\
\text { kulina }\end{array}$ & $\begin{array}{l}\text { Tumbuhnya cinta karena kebiasaan/ } \\
\text { intensi. }\end{array}$ \\
\hline & $\begin{array}{l}\text { Gudangan, gumolonging ke- } \\
\text { kadangan }\end{array}$ & Gudangan: menyatunya persaudaraan. \\
\hline \multirow[t]{3}{*}{$\begin{array}{l}\text { Mencegah } \\
\text { konflik }\end{array}$} & $\begin{array}{l}\text { Ana catur mungkur ana bapang } \\
\text { den simpangi }\end{array}$ & $\begin{array}{l}\text { Ada omongan (tidak baik) dibelakangi, } \\
\text { ada halangan disingkiri; tidak men- } \\
\text { dengarkan pembicaraan yang kurang } \\
\text { baik, berusaha menghindari munculnya } \\
\text { masalah. }\end{array}$ \\
\hline & Ana rembug dirembug & $\begin{array}{l}\text { Ada yang bisa dibicarakan harus dimu- } \\
\text { syawarahkan, jika ada permasalahan } \\
\text { maka harus dimus yawarahkan terlebih } \\
\text { dahulu untuk mencari pemecahannya. }\end{array}$ \\
\hline & Aja njiwit yen dijiwit lara & Jangan mencubit kalau dicubit sakit. \\
\hline
\end{tabular}




\begin{tabular}{|c|c|c|}
\hline \multirow[t]{6}{*}{$\begin{array}{l}\text { Sikap dalam ber- } \\
\text { konflik }\end{array}$} & Wani ngalah luhur wekasane & $\begin{array}{l}\text { Berani mengalah lebih tinggi derajatnya, } \\
\text { mulya di akhirnya. }\end{array}$ \\
\hline & Sing ngalah bakal oleh & $\begin{array}{l}\text { Barangsiapa yang mengalah malah akan } \\
\text { mendapat. }\end{array}$ \\
\hline & $\begin{array}{l}\text { Yen menang aja sawenang- } \\
\text { wenang }\end{array}$ & $\begin{array}{l}\text { Kalau menang jangan sewenang- } \\
\text { wenang. }\end{array}$ \\
\hline & Ngono yo ngono ning aja ngono & $\begin{array}{l}\text { Seperti itu yang seperti itu tapi tidak } \\
\text { mesti begitu; suatu tujuan tidak harus } \\
\text { dilakukan dengan satu cara tertentu tapi } \\
\text { bisa dengan cara lain yang meng- } \\
\text { hindarkan dari masalah baru. }\end{array}$ \\
\hline & Tega larane ora tegel patine & $\begin{array}{l}\text { sekejam-kejamnya pada saudara atau } \\
\text { keluarga tidak akan sampai hati men- } \\
\text { celakai sampai membunuh. }\end{array}$ \\
\hline & Bacin-bacin iwakala-ala sanak & $\begin{array}{l}\text { Sebau-baunya ikan sejelek-jeleknya sau- } \\
\text { dara, meskipun sejelek apapun saudara } \\
\text { tetap tidak akan disingkiri. }\end{array}$ \\
\hline \multirow{3}{*}{$\begin{array}{l}\text { Penyelesaian } \\
\text { konflik }\end{array}$} & Menang tanpa ngasorake & Menang tanpa menghinakan. \\
\hline & $\begin{array}{l}\text { Desa mawa cara negara mawa } \\
\text { tata }\end{array}$ & $\begin{array}{l}\text { Masing-masing daerah memiliki peratur- } \\
\text { an yang harus ditaati. }\end{array}$ \\
\hline & $\begin{array}{l}\text { Kena iwake aja nganti buthek } \\
\text { banyune }\end{array}$ & $\begin{array}{l}\text { Kena ikannya tanpa membuat keruh air; } \\
\text { menyelesaikan masalah tanpa mem- } \\
\text { buat masalah baru atau masalah di } \\
\text { lingkungannya. }\end{array}$ \\
\hline
\end{tabular}

Tabel 4.

Ungkapan Tradisional sebagai Antisipasi Kekerasan

\begin{tabular}{|c|l|l|}
\hline Jenis Kekerasan & Ungkapan Tradisional Jawa & \multicolumn{1}{c|}{ Makna } \\
\hline Kekerasan langsung & $\begin{array}{l}\text { yen menang aja sawenang- } \\
\text { wenang }\end{array}$ & $\begin{array}{l}\text { Jangan berlaku sewenang-wenang, } \\
\text { walaupun dalam posisi yang menang, } \\
\text { menguasai, atau menguntungkan. }\end{array}$ \\
\cline { 2 - 3 } & aja adigang adigung adiguna & $\begin{array}{l}\text { Jangan. menggunakan kekuasaan baik } \\
\text { kuasa ekonomi, kuasa jabatan maupun } \\
\text { kuasa pengetahuan untuk kesewenang- } \\
\text { wenangan pada orang lain. }\end{array}$ \\
\cline { 2 - 4 } & ojo mban cinde mban siladan & $\begin{array}{l}\text { Jangan membeda-bedakan, diskriminasi, } \\
\text { ketidakadilan. }\end{array}$ \\
\hline Kekerasan struktural & menang tanpangasorake & $\begin{array}{l}\text { Menang tanpa membuat orang lain } \\
\text { merasa kalah, win-win solution. }\end{array}$ \\
\hline
\end{tabular}




\begin{tabular}{|c|c|c|}
\hline & \multirow{2}{*}{$\begin{array}{l}\text { waningalah luhur wekasane } \\
\begin{array}{l}\text { yen menang aja sawenang- } \\
\text { wenang }\end{array}\end{array}$} & $\begin{array}{l}\text { Berani mengalah mulya akhirnya, tidak } \\
\text { memaksakan kehendak atau kepenting- } \\
\text { an diri untuk kepentingan bersama. }\end{array}$ \\
\hline & & $\begin{array}{l}\text { Jangan berlaku sewenang-wenang, } \\
\text { walaupun dalam posisi yang menang, } \\
\text { menguasai, atau menguntungkan. }\end{array}$ \\
\hline & aja adigang adigung adiguna & $\begin{array}{l}\text { Jangan. menggunakan kekuasaan baik } \\
\text { kuasa ekonomi, kuasa jabatan maupun } \\
\text { kuasa pengetahuan untuk kesewenang- } \\
\text { wenangan pada orang lain. }\end{array}$ \\
\hline & $\begin{array}{l}\text { Aja kaya pager mangan } \\
\text { tanduran }\end{array}$ & $\begin{array}{l}\text { Jangan seperti pagar makan tanaman, } \\
\text { jangan seperti orang yang diberi amanah } \\
\text { terutama kekuasaan agar tidak menye- } \\
\text { lewengkan amanah kekuasaan peme- } \\
\text { ritahan tersebut sehingga menyebabkan } \\
\text { kerusakan pada rakyatnya. } \\
\end{array}$ \\
\hline & asu gedhe menang kerahe & $\begin{array}{l}\text { Orang besar/pejabat lebih besar ke- } \\
\text { kuasaannya, Dalam masyarakat sudah } \\
\text { menjadi hal yang wajar demikian, tetapi } \\
\text { kalau mengunakan kekuasaan untuk } \\
\text { menindas orang atau pihak lain di- } \\
\text { pandang buruk sebagaimana binatang } \\
\text { anjing yang rendah nilainya di mata } \\
\text { manusia. }\end{array}$ \\
\hline \multirow[t]{3}{*}{ Kekerasan budaya } & tepaslira & $\begin{array}{l}\text { melihat pada diri sendiri apakah itu me- } \\
\text { nimbulkan ketidaknyamanan, ketidak- } \\
\text { senangan, menyakitkan pada diri sendiri, } \\
\text { yang apabila demikian maka kalau itu } \\
\text { diterapkan ke orang lain juga akan me- } \\
\text { rasakan hal yang sama. }\end{array}$ \\
\hline & deleng githoke dewe & $\begin{array}{l}\text { melihat tengkuknya sendiri, untuk } \\
\text { mengukur bahwa dirinya juga akan } \\
\text { mengalami hal yang sama kalau men- } \\
\text { dapatkan perlakuan sebagainya per- } \\
\text { lakuannya pada orang lain. }\end{array}$ \\
\hline & aja adigang adigung adiguna & $\begin{array}{l}\text { Jangan. menggunakan kekuasaan baik } \\
\text { kuasa ekonomi, kuasa jabatan maupun } \\
\text { kuasa pengetahuan untuk kesewenang- } \\
\text { wenangan pada orang lain. }\end{array}$ \\
\hline
\end{tabular}

Kerukunan di masyarakat terbangun melalui sikap pribadi warganya. Sesuai acuan moral atau etika Jawa, setiap orang dituntut untuk menunjukan 
sikap hormat dan rukun terhadap orang lain. Sikap dan perilaku yang mengarah pada hubungan sosial yang guyub rukun, dengan sendirinya akan mencegah terjadinya konflik dalam masyarakat. Setiap orang harus menekan kepentingan pribadinya untuk diselaraskan dengan kepentingan bersama, sehingga antara dirinya dengan lingkungannya terjadi harmonisasi.

Tindakan menekan keinginan sendiri untuk kepentingan bersama ini diungkapkan dengan istilah sepi ing pamrih rame ing gawe. Sikap pribadi yang sepi ing pamrih adalah sikap yang tidak menonjolkan ke-aku-an, dan menekan pamrih-pamrih pribadi. Dengan sikap demikian, maka mudah bagi seseorang untuk menyelaraskan diri dengan lingkungannya dan masyarakatnya sebagai satu kesatuan. Terlebih lanjutan ungkapan tadi, rame ing gawe, artinya giat dalam bekerja dalam pengertian tanggungjawab dalam kehidupan, seperti kesesuaian dengan hierarkhi tugas dan kewajibannya masing-masing dalam masyarakat. Sikap semacam ini akan mendorong setiap anggota masyarakat menyesuaikan diri dengan nilai-nilai yang dipegang bersama, sehingga pada akhirnya dalam mewujud dalam bentuk masyarakat yang guyub rukun tersebut.

Dengan demikian nilai sepi ing pamrih rame ing gawe mewujud dalam sikap-sikap seperti andhap ashor (rendah hati) dan prasaja (sederhana) karena mampu mengekang rasa ke-aku-an. Sikap-sikap ini mendorong penghormatan pada orang lain, tata krama, subasita, unggah-ungguh, yang pada akhirnya menghindarkan diri dari gesekan dan pertentangan, atau $\mathrm{crah}$ dengan pihak lain. Wujud sikap lainnya adalah welas asih atau kasih sayang dan tresna atau cinta. Adanya welas asih dan tresna ini mendorong setiap orang untuk berbuat baik, kemauan menolong orang lain, saling membantu dan bekerjasama. Sikap welas asih ini juga menumbuhkan empati terhadap penderitaan dan kebutuhan orang lain, sehingga dalam berhubungan dengan orang lain akan dilandasi sikap kasih sayang. Hal ini tentu saja mendukung munculnya kerukunan dalam interaksi sosial dan berrelasi dengan orang lain.

Saat interaksi diwarnai dengan munculnya perbedaan dan pertentangan, maka dalam menghadapi konflik ini, pribadi-pribadi dituntut untuk bersabar. Sikap sabar adalah sikap legawa untuk mengalah. Itu sebabnya muncul ungkapan sapa wani ngalah dulur wekasane, sabar duwur wekasane, sapa ngalah bakal oleh, dan sebagainya. Sikap sabar dan wani ngalah ini, 
bukan berarti membiarkan diri diinjak-injak. Karena itu ada ungkapan $n g a l a h$ ngalih ngamuk, di mana untuk menjaga harmoni orang Jawa akan memilih mengalah agar tidak terlibat konflik secara terbuka. Apabila masih terus ditekan, ia akan menyingkir dan menghindari masalah atau konflik, ana catur mungkur ana bapang den simpangi. Namun jika masih juga mendapat tekanan dan agresi, maka yang muncul adalah sikap sedumuk bathuk senyari bumi, yakni membela harga diri dan kepemilikannya walau dengan nyawa taruhannya.

Dengan demikian mentalitas pribadi yang mendukung harmonisasi ini, selain terinternalisasi sebagai sikap mental masing-masing orang, sekaligus tereksternalisasi menjadi nilai-nilai kolektif yang mencegah orang lain berlaku otoriter, agresi, dan perilaku lainnya yang dapat menimbulkan crah. Sikap mental ini akan mendorong terwujudnya guyub rukun dalam masyarakat, sehingga mencapai rukun agawe santosa, sekaligus mencegah crah agawe bubrah.

\section{G. Guyub Rukun sebagai Pandangan Sosial Masyarakat Ganjuran}

Kehidupan bermasyarakat di wilayah Ganjuran berjalan dengan damai, termasuk di dalamnya hubungan antarumat Islam dan umat Katolik saling berrelasi dengan rukun. Kerukunan di Desa Sumbermulyo terbangun dari budaya lokal, yang berbasis pada budaya Jawa yang sangat menekankan sikap guyub rukun dalam kehidupan bersama. Berbagai ungkapan tradisional yang berisi pesan-pesan moral untuk memelihara hubungan baik dan menghindari konflik dengan orang lain. Ungkapan-ungkapan tersebut menjadi nilai-nilai dan acuan moral dalam menjalani relasi sosial, sehingga interaksi dengan orang lain berjalan dengan penuh kedamaian. Demikian pula dalam berbagai tradisi yang dijalankan oleh masyarakat, merupakan tradisi yang lintas agama sehingga membangun ikatan solidaritas antarwarga dan menekan potensi konflik antarumat beragama. Tradisi-tradisi yang dilakukan masyarakat Ganjuran memiliki nilai yang memperkuat kohesi sosial, sekaligus di dalamnya mengandung transformasi berupa simbolisasi makna spiritual maupun kerukunan bagi kehidupan masyarakat. Ungkapanungkapan tradisional maupun praktek-praktek tradisi tersebut mengarah pada kehidupan bermasyarakat yang guyub rukun. 
Budaya guyub rukun ini selaras dengan orientasi hidup masyarakat Jawa yaitu mencapai hidup yang harmoni, dengan Tuhan, lingkungan, dan diri sendiri. Berbagai aspek kehidupan orang Jawa diwarnai dengan tujuan mencapai keseimbangan diri dan harmoni berupa keselarasan dengan Tuhan, lingkungan alam, lingkungan sosial atau masyarakat, dan dengan dirinya sendiri yakni diri yang lahir dengan diri yang batin. Kerukunan dengan sesama manusia sebagai lingkungan sosial, termasuk kerukunan umat beragama, menjadi bagian tujuan hidupnya yaitu mencapai hidup yang harmoni tersebut.

Keseimbangan berupa keharmonisan hidup tersebut merupakan kesadaran kosmis yang melingkupi kehidupan seseorang yang sadar sebagai orang Jawa. Yakni kesadaran diri untuk senantiasa menyelaraskan keharmonisan antara jagat alit (mikrokosmos) dengan jagat ageng (makrokosmos). Kesadaran tersebut diungkapkan lewat falsafah sangkan paraning dumadi, kesadaran terhadap asal usul dan tujuan penciptaan. Semua berasal dari dan akan kembali kepada Tuhan Yang Maha Esa. Tuhan menjadi asal, sekaligus berada di dalam, serta menjadi tujuan semua kejadian, sehingga kesatuan dan keselarasan menjadi suatu hal yang penting. Sebagaimana diungkapkan dalam penelitian Niels Mulder ${ }^{1}$, bahwa keteraturan berarti harmoni dengan tujuan kosmos, dan dalam arti terdalam menjadi kemanunggalan, kesatuan dari segala-galanya, pencipta dengan yang diciptakan, kawula dengan gusti, sangkan paran, di mana prinsip kesatuan ini sebagai Tuhan. Dengan demikian tugas penting manusia adalah menjaga ketertiban yang sesungguhnya menjadi kehendak Tuhan dan fitrah kehidupan ini. Bahkan oleh karena ketertiban sudah menjadi fitrah, maka tugas manusia bukan menciptakan ketertiban melainkan hanya menjaga ketertiban tersebut. Itulah yang diungkapkan melalui sepi ing pamrih rame ing gawe.

Makna sepi ing pamrih rame ing gawe adalah bahwa tindakan manusia harus dibebaskan dari pamrih atau kepentingan pribadi, dan hanya bertindak sebagai tanggungjawab sesuai dengan posisinya dalam masyarakat atau kehidupan ini. Pamrih merupakan sumber dari konflik dan pertentangan dalam

1 Niels Mulder, Kebatinan dan Hidup Sehari-hari Orang Jawa, Kelangsungan dan Perubahan Kulturil, (Jakarta: Gramedia, 1980), h. 14-15. 
kehidupan, dan tanggungjawab menjadi penyangga keselarasan kehidupan apabila tidak dilaksanakan akan mengganggu keselarasan dan harmoni kehidupan. Sepi ing pamrih merupakan usaha sadar untuk melawan hawa nafsu dalam rangka usaha mencapai ketenangan hati dan kebijaksanaan, melalui pengekangan diri sehingga menimbulkan sikap penuh kebaikan terhadap orang lain bahkan terhadap umat manusia seluruhnya. ${ }^{2}$

Dengan kesadaran atau kawruh sangkan paraning dumadi yang diwujudkan dalam bentuk sepi ing pamrih rame ing gawe, maka interaksi dan berrelasi dengan liyan atau orang lain menjadi harmoni. Oleh karena itu dalam konsep konsep aku pribadhi bagi orang Jawa bukanlah suatu keberdiri-sendirian yang menjadi pusat otonomi dan tanggungjawab, tetapi aku orang Jawa adalah dwi-tunggal bahkan tri-tunggal (untuk menyebut jamak) yang berarti adalah aku dan orang lain yang dekat yang sudah diakui dan diakukan. Liyan adalah siapa saja yang berada di luar keakuan tersebut. ${ }^{3}$

Pribadhi dan liyan menjadi ke-aku-an hanya jika pribadi-pribadi dapat bersikap rukun. Sikap rukun inilah yang menjamin terwujudnya keselarasan dan harmoni. Sikap rukun berarti sikap perdamaian, kerukunan, keselarasan, dan harmoni tanpa pertentangan dan konflik dalam kehidupan. Sikap rukun harus ditunjukkan dalam hubungannya dengan pribadi yang lain yang telah diakui dan diakukan melalui sikap guyub, yakni mau mengenal, bersedia bersama, dan beraktivitas bersama, sebagai satu kesatuan yang selaras dan harmoni sebagai menjadi keselarasan dengan sangkan paraning dumadi.

Pada akhirnya, manusia dapat melaksanakan tanggungjawab kehidupan yang hayu atau indah, sebagai kehendak sangkan paraning dumadi. Hal ini diungkapkan dengan memayu hayuning bawana, memperindah-indahkan keindahan semesta. Manusia tanpa berpretensi membuat keindahan karena sesungguhnya keindahan sudah adikodrati dalam asal dan tujuan penciptaan kehidupan ini. Manusia hanya dituntut untuk sepi ing pamrih rame ing gawe, melalui guyub rukun dalam upaya memayu hayuning bawana. Diungkapkan

2 Niels Mulder, Kebatinan dan Hidup Sehari-hari Orang Jawa, Kelangsungan dan Perubahan Kulturil, (Jakarta: Gramedia, 1980), h. 39.

3 Franz Magnis Suseno dan Reksosusilo, Etika Jawa dalam Tantangan (Sebuah Bunga Rampai), (Yogyakarta: Penerbit Kanisius, 1983), h. 141-142. 
Suseno ${ }^{4}$ bahwa setiap orang dalam sikap individualnya hendaknya melakukan apa yang dituntut oleh kewajiban pangkatnya -sepi ing pamrih rame ing gawe, hal mana dengan sendirinya berarti telah menyesuaikan diri dengan masyarakat (rukun) dan mengakui tatanan (hormat). Dengan cara ini maka manusia memberi sumbangan paling optimal terhadap keselarasan dalam masyarakat dan kesejahteraan umum, serta akan mencapai ketenangan batin bagi dirinya melalui kelesarasan dan harmoni tersebut. Dunia atau semesta yang indah, yang terwujud dalam keselarasan dan harmoni akan dapat dicapai dalam kehidupan ini.

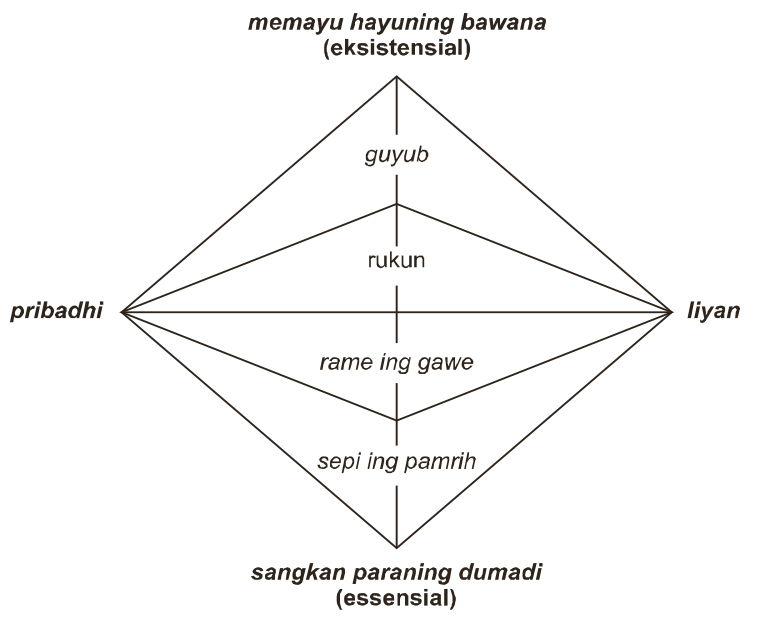

Gambar 1.

Pandangan Sosial Orang Jawa

Kehidupan yang penuh harmoni dipandang akan menumbuhkan kekuatan, itulah yang dimaksudkan dengan rukun agawe santosa. Santosa atau kekuatan yang dimaksud adalah bentuk ketahanan sosial baik bagi dirinya sendiri maupun untuk kehidupan bersama-sama dalam masyarakat. Kasantosan atau kekuatan tersebut hanya akan tercapai apabila semua orang melakukan tugas dan tanggungjawabnya dengan baik, dan menanggalkan

\footnotetext{
4 Franz Magnis Suseno, Etika Jawa, Sebuah Analisa Falsafi tentang Kebijaksanaan Hidup Jawa, (Jakarta: PT. Gramedia Pustaka Utama, 2003), h. 149.
} 
pamrih-pamrih pribadi yang memicu pertentangan dan konflik. Adanya pertentangan dan konflik atau crah akan menyebabkan rusaknya tatanan, mengganggu ketertiban sehingga kehidupan menjadi rapuh dan akhirnya bubrah atau rusak.

Dalam konteks masyarakat Ganjuran, di mana terdapat umat Islam, dan umat Katolik, maka nilai-nilai ajaran agama juga menjadi sumber acuan perilaku dan sikap, di samping acuan perilaku dari budaya Jawa. Ajaran agama yang berbeda dapat menjadi sumber pertentangan atau konflik, tetapi dalam ajaran agama juga terdapat nilai-nilai yang saling sejalan. Pandangan budaya Jawa yang mengedepankan guyub rukun, menjadi acuan relasional antara umat Islam dan umat Katolik, sehingga dalam bermasyarakat lebih mengedepankan nilai-nilai yang selaras. Masing-masing kelompok umat mennyelaraskan diri dalam tradisi kebersamaan atau guyub rukun melalui srawung dalam berbagai aktivitas sosial, dengan menekan perbedaanperbedaan di antara mereka dalam konteks sosial. Hal ini menjadikan masyarakat Ganjuran yang berbeda agama dapat hidup rukun dan damai.

\section{H. Kesimpulan}

Masyarakat Ganjuran di Desa Sumbermulyo Kecamatan Bambanglipuro Bantul Yogyakarta terpilah berdasarkan agama, adalah umat Islam, Katolik dan Kristen. Namun demikian masyarakat ini telah terkenal masyarakat yang rukun dan damai. Namun tidak dipungkiri, dalam hubungan antarumat beragama, terlebih dalam konteks masyarakat yang heterogen, terjadi dinamika dalam interaksi sosialnya. Meskipun demikian, secara umum lingkungan Ganjuran interaksi sosial yang terjalin di dalamnya berjalan dengan baik, terutama karena didukung dengan budaya Jawa yang melingkupi masyarakat Ganjuran.

Situasi yang rukun dan damai dalam lingkungan masyarakat Ganjuran, diantaranya ditopang dengan adanya budaya Jawa yang menjadi latar belakang budaya masyarakat Ganjuran. Budaya Jawa ini sangat menekankan kehidupan yang harmonis, damai dan rukun dalam bentuk sikap penghormatan, sikap rukun, toleransi, dan sebagainya menjadi acuan moral dan tingkah laku dalam berhubungan antarumat beragama. Nilai-nilai budaya ini dikristalisasi dalam bentuk ungkapan-ungkapan tradisional.[w] 


\section{BIBLIOGRAFI}

Amirrachman, Alpha, Revitalisasi Kearifan Lokal: Studi Resolusi Konflik di Kalimantan Barat, Maluku dan Poso, Jakarta: ICIP dan European Commission (EC), 2007, www.lsaf.org/content/view/176/150/ diunduh 17 Juni 2010.

Data Potensi Desa Sumbermulyo tahun 2012.

Geertz, Hildred, Keluarga Jawa, Jakarta: Grafiti Press, 1985.

Haba, John, Revitalisasi Kearifan Lokal: Studi Resolusi Konflik di Kalimantan Barat, Maluku, dan Poso, Jakarta: ICIP dan Eropean Commision, 2007.

Haryanto, Joko Tri, “Norma Nyama Braya bagi Kerukunan Umat Beragama: Studi terhadap Masyarakat Angantiga Bali", Jurnal Harmoni Puslitbang Kehidupan Keagamaan Kementerian Agama, Volume X, Nomor 2, April - Juni 2011.

Jamil, M. Mukhsin, dkk., Mengelola Konflik Membangun Damai, Semarang: Walisongo Mediation Center (WMC), 2010.

Khalim, Samidi, Tradisi Lisan Masyarakat Jawa, Semarang: Prima Media Press, 2009.

Laporan Pembangunan Desa Sumbermulyo tahun 2011.

Mulder, Niels, Kebatinan dan Hidup Sehari-hari Orang Jawa, Kelangsungan dan Perubahan Kulturil, Jakarta: Gramedia, 1980.

Nasrullah, Arif, "Hubungan Muslim-Hindu di Lombok Barat (Analisis Kerukunan dan Potensi Konflik Islam-Hindu di Gunugsari Lombok Barat NTB)", Tesis, Yogyakarta: Program Pascasarjana UIN Sunan Kalijaga, 2012.

Rohimin, etal, Harmonisasi Agama dan Budaya di Indonesia, Jakarta: Balai Litbang Agama Jakarta, 2009.

Soekanto, Suryono, Sosiologi Suatu Pengantar, Jakarta: PT. Raja Grafindo, 1982.

Sulaiman, dkk, Menguak Makna Kearifan Lokal pada Masyarakat Multikultural. Semarang: Robar Bersama, 2011.

Susan, Novri, Pengantar Sosiologi Konflik dan Isu-Isu Konflik Kontemporer, Jakarta: Kencana Predana Media Group, 2010.

Walisongo, Volume 21, Nomor 2, November 2013 
Suseno, Franz Magnis, Etika Jawa, Sebuah Analisa Falsafi tentang Kebijaksanaan Hidup Jawa, Jakarta: PT. Gramedia Pustaka Utama, 2003.

Suseno, Franz Magnis dan Reksosusilo, Etika Jawa dalam Tantangan (Sebuah Bunga Rampai), Yogyakarta: Penerbit Kanisius, 1983.

\section{Internet:}

Nurhayati, Endang, "Nilai-Nilai Luhur dalam Ungkapan Jawa sebagai Fondamen Kehidupan Masyarakat Berbudaya", makalah, Konggres Bahasa Jawa ke-5 dikutip dalam http://ki-demang.com/kbj5, diunduh 14 September 2012

Widyastuti, Sri Harti, "Reaktualisasi Ungkapan Tradisional Jawa Sebagai Sumber Kearifan Lokal dalam Masyarakat untuk Penguat Kepribadian Bangsa", makalah, Konggres Bahasa Jawa ke-5 dikutip dalam http://kidemang.com/kbj5, diunduh 14 September 2012. 